\title{
Haematological response of Labeo rohita (Hamilton) fingerlings exposed to low salinities
}

\author{
SUPRIYA RANI, T. S. NAGESH, G. DASH AND T. J. ABRAHAM \\ Department of Fisheries Resource Management, Faculty of Fishery Sciences, West Bengal University of \\ Agriculture and Fisheries Sciences, 5 Budherhat Road, Chakgaria, P. O. Panchasayar, Kolkata - 700094 \\ West Bengal, India \\ e-mail: tsnagesh2@rediffmail.com
}

\begin{abstract}
The present study was carried out for a period of 42 days to find out the effect of different acclimation salinities (0-control, 2, 4, 6 and 8 ppt) on the haematology of Labeo rohita fingerlings. The fish remained active and showed normal feeding and swimming behaviour up to $4 \mathrm{ppt}$ salinity level; however, at 6 and $8 \mathrm{ppt}$, they get stressed but were able to survive. There was no significant difference in haematological parameters among fishes in the control, 2 and 4 ppt treatments. Haematocrit $(\mathrm{Ht} \%)$ values were within the optimum range at 0,2 and 4 ppt salinity. The mean haematocrit values ranged from 22.21 (at $8 \mathrm{ppt)}$ to 27.03 (control). The highest mean haemoglobin content was observed at $0 \mathrm{ppt}\left(7.09 \mathrm{~g} \mathrm{dl}^{-1}\right)$ and it was lowest at $8 \mathrm{ppt}$ salinity $\left(5.36 \mathrm{mg} \mathrm{dl}^{-1}\right)$ on the day of termination of the experiment. Mean total erythrocyte count (TEC) was highest $\left(1.83 \times 10^{6} \mathrm{~mm}^{-3}\right)$ at $2 \mathrm{ppt}$ salinity and the lowest was at $8 \mathrm{ppt}$ salinity $\left(1.52 \times 10^{6} \mathrm{~mm}^{-3}\right)$. The mean total leukocyte count (TLC) was highest at $8 \mathrm{ppt}\left(4.81 \times 10^{3} \mathrm{~mm}^{-3}\right)$ and the lowest value was recorded at $0 \mathrm{ppt}\left(4.35 \times 10^{3} \mathrm{~mm}^{-3}\right)$. The mean plasma glucose level at $8 \mathrm{ppt}\left(62.43 \mathrm{mg} \mathrm{dl}^{-1}\right)$ was the highest among the different groups and lowest of $44.70 \mathrm{mg} \mathrm{dl}^{-1}$ was seen in control fishes. Results of the study indicated that increasing salinity up to a certain level is tolerated by $L$. rohita through osmoregulation, however, extreme salinity stress can lead to alterations in the haematology as well as physiology and further the inability to adapt, leads to metabolic downregulation, thereby affecting growth.
\end{abstract}

Keywords: Haematology, Labeo rohita fingerlings, Salinity

Aquaculture, one of the fastest growing food producing sectors, is playing a significant role in providing nutrition over the years. Among the Indian major carps, Labeo rohita (Hamilton) commonly called as rohu is the most preferred species because of certain advantages such as ability to thrive well in shallow waters, high market demand, good growth rate, omnivorous feeding habit and acceptability to artificial diets. India has enormous and diverse range of fishery resources including 1.235 million ha of brackishwater, which is characterised by a low saline and high saline phase. At present only about $15 \%$ of the total potential brackishwater area has been brought under culture and vast areas of brackishwater remain unutilised during the low saline phase primarily due to non-availability of seeds of suitable fish species for stocking. The freshwater region in the coastal belt also comes under the influence of saline water during summer months, posing threat to culture of freshwater species. It is therefore, important to know the tolerance, physiological responses and growth performance of commercially important freshwater species under salinity stress. This information would help aquaculturists to take up freshwater aquaculture in the areas subjected to saline influence.
Studies on the tolerance of salinity of Indian major carps revealed that they can withstand salinities up to $10 \mathrm{ppt}$ but for satisfactory growth, salinity should not exceed 5 ppt (Billard, 1999). Pillai et al. (2003) studied the effect of salinity ranging from 0-14 ppt on L. rohita and observed that the species can survive in waters up to $8 \mathrm{ppt}$ salinity. Though studies on effect of salinity on growth performance have been reported (Ghosh and Pandit, 1976), studies on metabolic activity or physiological demand as well as haematological response of these species, however are sparse (Routray and Routray, 1997). In recent years, haematology has been used as a tool to assess the physiological conditions in healthy, stressed or diseased fishes and also in toxicological screening of fish as test species. In view of the expanding culture of L. rohita and lack of information on haematology of this species under low salinity levels, the present investigation was undertaken to study the effect of different levels of salinity (within the limits of tolerance of the species), on the haematology of L. rohita fingerlings.

Perceptibly healthy fingerlings of $L$. rohita $(9.1-12.7 \mathrm{~cm})$ were obtained from Jhattu fish pokhar, 
Tollygunj, Kolkata. Fishes were acclimatised to laboratory conditions for one week in fresh tap water in 5001 FRP tanks provided with continuous aeration. Experimental fish were fed with pelleted feed (38\% protein) @ $5 \%$ body weight. Faecal matter and unutilised feed materials were siphoned out and $25-30 \%$ of water exchange was done with freshwater on every alternative day. Artificial saline water (35 ppt) was prepared (APHA, 1998) for the experimental purpose as stock. Test salinity ranging from 0 (control; fresh tap water) to 8 ppt at 2 ppt intervals (i.e., 2, 4, 6 and $8 \mathrm{ppt}$ ) were prepared by dilution from stock saline water.

Acclimatised fishes were then segregated and stocked in cleaned and dried glass aquaria $\left(60 \times 30 \times 30 \mathrm{~cm}^{3}\right) @ 5$ numbers per aquaria in triplicates with almost uniform size as per completely randomised design. Aquaria were filled with water up to a depth of $20 \mathrm{~cm}$ and aeration was continued during the experiment. Salinity was gradually increased by 2 ppt every alternative day to the required levels. The depth and test salinities $(0,2,4,6$ and $8 \mathrm{ppt})$ were maintained throughout the experimental period. Pelleted feed was given at $5 \%$ of the body weight, throughout the experimental period. Faecal matter and uneaten feed were siphoned out daily and water of respective salinities was exchanged to compensate the loss. The experiment was carried out for a period of 42 days. Response of fishes to changes in salinity levels were observed on daily basis and for any change in the normal behaviour of experimental fishes in comparison to control. Changes in activities like swimming, surfacing and feeding were also monitored and recorded.

Fishes were sampled fortnightly at random from each replicate aquaria using scoop net with minimum handling stress and transferred into plastic buckets containing water of the same salinities as in the experimental tanks. Blood samples were collected by cardiac puncture using $1 \mathrm{ml}$ (40 divisions) disposable insulin syringe treated with trisodium citrate $(3.8 \%)$ as anticoagulant and transferred to $1.5 \mathrm{ml}$ eppendorf tubes rinsed with the anticoagulant and mixed well to prevent coagulation. The collected blood samples were immediately subjected to haematological analyses (Blaxhall and Daisley, 1973). Haematocrit (Ht) was determined by drawing blood by capillary action into microhaematocrit tubes. One end of the tube was sealed with plasticine. The sealed tube was then centrifuged in a microhaematocrit centrifuge at $10,500 \mathrm{rpm}$ for $5 \mathrm{~min}$. The haematocrit value was expressed as the percentage fraction of blood cells in the total blood volume. Total erythrocytes count (TEC) and total leucocytes count (TLC) of fish blood were done in Neubauer haemocytometer using Hayem's fluid and Shaw's W. B. C. fluid as diluents, respectively. Counts were made in triplicates for each blood samples.
The TEC and TLC values were expressed as millions per cubic millimeter and thousands per cubic millimeter, respectively. Haemoglobin concentration was determined by acid hematin method using Sahli's haemoglobinometer.

For serum collection, the blood sample, drawn with $1 \mathrm{ml}$ disposable insulin syringe without using anticoagulant, was transferred to $1.5 \mathrm{ml}$ eppendorf tube and allowed to clot for $60 \mathrm{~min}$ by keeping the tube in slanting position. The blood clots giving a straw coloured supernatant at the top was then centrifuged in a micro centrifuge (SPINWIN MC-00, Tarsons) at a fixed speed of $2000 \mathrm{~g}$ for $15 \mathrm{~min}$. The supernatant was collected, transferred to eppendorf tube and stored at $-20^{\circ} \mathrm{C}$ for further analysis. The straw coloured serum was immediately separated from the centrifuged blood cells at the bottom with a micro-pipette and transferred to $0.5 \mathrm{ml}$ eppendorf tubes and stored in the refrigerator until glucose estimation. The serum glucose was determined using glucose test kit (Span Diagnostic Ltd.) following GOD-POD method using spectrophotometer. Other haematological parameters were estimated following Blaxhall and Daisley (1973). All results are expressed as mean \pm SD. The significant difference if any in the mean values of each haematological parameter among different salinities was analysed by oneway analysis of variance at 0.05 level of significance using SPSS statistical package. When $F$ values indicated significance $(\mathrm{p}<0.05)$, difference between the means was examined using Duncan's multiple range test (Snedecor and Cochran, 1980).

Haematological parameters of L. rohita fingerlings at different salinities are presented in Table 1. Information on haematological parameters of fish is essential for early diagnosis of disease and for studying the effect of stress. The mean values of $\mathrm{Ht}(27.03 \%), \mathrm{Hb}\left(7.09 \mathrm{~g} \mathrm{dl}^{-1}\right)$, TEC $\left(1.83 \times 10^{6} \mathrm{~mm}^{-3}\right)$, TLC $\left(4.35 \times 10^{6} \mathrm{~mm}^{-3}\right)$ and plasma glucose $\left(44.70 \mathrm{mg} \mathrm{dl}^{-1}\right)$ levels of $L$. rohita fingerlings obtained for the control ( 0 ppt salinity) were found within the normal ranges established by Das et al. (2004). However, the values given by Siddiqui and Naseem (1979) for $\mathrm{Ht} \%, \mathrm{Hb}, \mathrm{TLC}$ and TEC in L. rohita were found to be higher than the present experimental values, which might be attributed to larger size of fish. The variation in normal haematological parameters of fish are known to be caused by environment stress (Hickey and Ferrari, 1982; Aldrin et al., 1982), malnutrition (Casillas and Smith, 1977), gender (Collazos et al., 1998) and fish size (Garcia et al., 1992). There was no significant difference in hamematological parameters among control, 2 and 4 ppt fishes and between fishes from 6 and 8 ppt treatments. There was significant $(p<0.05)$ difference in the haematological parameters of fishes in 6 and 8 ppt salinities with that of control, 2 and 4 ppt salinites. 
Table 1. Haematological parameters (Mean $\pm \mathrm{SD}$ ) of Labeo rohita fingerlings exposed to different salinities

\begin{tabular}{llcccc}
\hline \multirow{2}{*}{ Haematological parameter } & \multicolumn{5}{c}{ Salinity level (ppt) } \\
\cline { 2 - 6 } & Control $(0)$ & 2 & 4 & 6 & 8 \\
\hline Haematocrit value $(\mathrm{Ht} \%)$ & $27.03 \pm 1.57^{\mathrm{a}}$ & $27.05 \pm 1.52^{\mathrm{a}}$ & $27.03 \pm 1.56^{\mathrm{a}}$ & $23.74 \pm 1.14^{\mathrm{b}}$ & $22.21 \pm 1.97^{\mathrm{b}}$ \\
Haemoglobin concentration $\left(\mathrm{g} \mathrm{dl}^{-1}\right)$ & $7.09 \pm 0.39^{\mathrm{a}}$ & $7.03 \pm 0.39^{\mathrm{a}}$ & $6.93 \pm 0.76^{\mathrm{a}}$ & $5.91 \pm 0.67^{\mathrm{b}}$ & $5.36 \pm 1.02^{\mathrm{b}}$ \\
Total erythrocyte count $\left(\mathrm{x} 10^{6} \mathrm{~mm}^{-3}\right)$ & $1.83 \pm 0.20^{\mathrm{a}}$ & $1.79 \pm 0.21^{\mathrm{a}}$ & $1.77 \pm 0.12^{\mathrm{a}}$ & $1.55 \pm 0.05^{\mathrm{b}}$ & $1.52 \pm 0.04^{\mathrm{b}}$ \\
Total leucocytes count $\left(\mathrm{x} 10^{3} \mathrm{~mm}^{-3}\right)$ & $4.35 \pm 0.04^{\mathrm{a}}$ & $4.48 \pm 0.28^{\mathrm{a}}$ & $4.38 \pm 0.09^{\mathrm{a}}$ & $4.69 \pm 0.22^{\mathrm{b}}$ & $4.81 \pm 0.22^{\mathrm{b}}$ \\
Plasma glucose $\left(\mathrm{mg} \mathrm{dl}^{-1}\right)$ & $44.70 \pm 0.21^{\mathrm{a}}$ & $44.78 \pm 0.27^{\mathrm{a}}$ & $45.03 \pm 0.67^{\mathrm{a}}$ & $48.90 \pm 2.15^{\mathrm{b}}$ & $62.43 \pm 13.03^{\mathrm{b}}$ \\
\hline
\end{tabular}

Mean values with different superscripts in the same row differ significantly $(p<0.05)$

The mean $\mathrm{Ht} \%$ varied significantly $(\mathrm{p}<0.05)$ at higher salinities (23.74 at $6 \mathrm{ppt}$ and 22.21 at $8 \mathrm{ppt}$ ) with respect to control. The $\mathrm{Ht} \%$ values recorded in the present study are within the optimum range of $L$. rohita at 0 ppt (27.03), $2 \mathrm{ppt}(27.05)$ and $4 \mathrm{ppt}(27.03)$ but it is below the optimum range at $6 \mathrm{ppt}(23.74)$ and $8 \mathrm{ppt}$ (22.21) towards the end of the experiment, which might be due to the seasonal variations in haematological parameters, being generally high during summer and monsoon months but low during winter (Siddiqui and Naseem, 1979). L. rohita could be physiologically active within the optimum range of $0-4$ ppt salinity as noticed by Das et al. (2004) and hence was not stressful to the fishes to cause any change in the blood physiology. The decline in $\mathrm{Ht} \%$ at $8 \mathrm{ppt}$ level might be due to metabolic and cardiac depression (Zhou and Lloyd, 2000; Farrell and Robertson, 2002) which might have led to the decrease in blood volume. A closely similar variation in $\mathrm{Ht} \%$ was reported by Hattingh (1976) in Labeo capensis.

The highest mean haemoglobin content was observed at 0 ppt $\left(7.09 \mathrm{~g} \mathrm{dl}^{-1}\right)$ and it was lowest at 8 ppt salinity $\left(5.36 \mathrm{~g} \mathrm{dl}^{-1}\right)$ on the day of termination of the experiment. Dheer (1986) reported inconsistent levels in haemoglobin with salinity variations in Channa punctatus. However, the haemoglobin content in the present study showed a decrease at 6 and 8 ppt salinities towards the termination of experiment. The decline could be correlated with behavioural observations made during the experiment which showed higher feeding activity at 0 and $2 \mathrm{ppt}$ salinity and fishes were reluctant to feed or reduced feeding activity which is often symptomatic of physiological stress at higher salinities (Elliot, 1981).

Fortnightly observations on TEC, revealed a clear cut increase in the total count up to 2 ppt salinity. From 4 ppt salinity onwards TEC showed a decline in number. The highest TEC counts were found at $0 \mathrm{ppt}\left(1.83 \times 10^{6} \mathrm{~mm}^{-3}\right)$ and the lowest was at $8 \mathrm{ppt}$ salinity $\left(1.52 \times 10^{6} \mathrm{~mm}^{-3}\right)$. The lower value might be due to the slight variations in the fish size (Garcia et al., 1992) or seasonal differences (Cech and Wohlschlag, 1981). The present findings corroborated the reports of Dheer (1986) who has also recorded a decrease in the erythrocyte count with increase in salinity. Adjustments to blood characteristics are very common when fish are exposed to stress (Randall and Prey, 1994). At 0 and 2 ppt salinities, fishes showed behavioural changes like active swimming and active feeding while at 4,6 and 8 ppt salinities the fishes curtailed their general feeding activity which might have caused metabolic depression.

The overall mean TLC was highest at $8 \mathrm{ppt}$ $\left(4.84 \times 10^{3} \mathrm{~mm}^{-3}\right)$ and lowest at 0 ppt $\left(4.35 \times 10^{3} \mathrm{~mm}^{-3}\right)$. The TLC values were significantly $(\mathrm{p}<0.05)$ lower at 2 , 4 and 6 ppt salinity with respect to control and varied insignificantly $(p>0.5)$ among each other. TLC values decreased up to 4 ppt salinity and increased there onwards. TLC may increase with stress as the leukocytes are involved in the regulation of immunological function and protective response in fish to stress (Hymarathi and Rao, 1999). The increase in TLC at 6 and 8 ppt could be attributed to increase in thrombocytes, lymphocytes or squeezing of WBC in peripheral blood (Agarwal and Sriwastava, 1980). Increase in the TLC could also be due to stimulated lymphopoiesis and/or enhanced release of lymphocytes from lymphomyeloid tissue as has been opined by Meenakala and Gundersen (1978). The stress induced elevation of plasma cortisol also has a direct cytolytic effect on lymphocytes (Wiik and Hoffman, 1989; Engelsma and Frott, 2003). A low WBC count may mean dysfunction in haematological tissues such as spleen and kidney.

The mean glucose at $8 \mathrm{ppt}\left(62.43 \mathrm{mg} \mathrm{dl}^{-1}\right)$ was highest than in all other salinities. The lowest mean glucose content was found at control $(0 \mathrm{ppt})\left(44.70 \mathrm{mg} \mathrm{dl}^{-1}\right)$ followed by $2 \mathrm{ppt}\left(44.72 \mathrm{mg} \mathrm{dl}^{-1}\right)$ and $4 \mathrm{ppt}\left(45.03 \mathrm{mg} \mathrm{dl}^{-1}\right)$. Salinity differed insignificantly $(\mathrm{p}>0.05)$ among each other. A similar study by Dheer (1986) on Channa punctatus reported a progressive increase in glucose at the two higher salinities of 6 and 8 ppt whereas at 2 ppt they were the same as that of control. The present investigation reported hyperglycaemia in the fishes in response to salinity stress which agrees with several previous findings (Wedemeyer 1972; Strange and Spencer, 1977). Under sub-optimum and stressful conditions (internal 
or external) the chromaffin cells release catecholamines viz., adrenaline and noradrenaline in the blood (Reid and Nelson, 1998). These stress hormones in conjunction with cortisol mobilise and elevate glucose production in fish through gluconeogenesis and glycogenolysis pathways (Iwama et al., 1999) to cope with the energy demand produced by the stressors. Glucose is then released (from liver and muscle) towards blood circulation and enters into cells through the insulin action (Nelson and Cox, 2005). Omeregie and Golden (1990) reported that tilapia showed marked hyperglycaemic response to stressed environmental conditions as a result of incomplete metabolism of the blood sugar due to impaired osmoregulation. When the fishes are metabolically inactive, the respiratory metabolism is depressed and therefore stored intracellular glycogen is utilised. Under such conditions, the hyperglycaemic hormone is released for the degradation of glucose. This glucose enters the blood causing hyperglycaemia (Bhattacharya et al., 1987).

It has been illustrated that the use of haematological variables as indicators of stress can provide information on the physiological response of fish to a changing external environment. Increasing salinity up to a certain level is tolerated by fingerlings of L. rohita through osmoregulation, thereby they bring about adaptive physiological changes in order to compensate, partially or completely. However, extreme salinity stress can have alterations on haematology and internal physiology, and finally inability to adapt leads to metabolic depression, thereby affecting growth.

\section{References}

Agarwal, S. H. and Sriwastava, F. H. 1980. Evaluation of poultry feather meal as dietary protein source for Cyprinus carpio. Aquaculture, 45: 23-26.

Aldrin, J. F., Messager, J. L., Laurencin, F. B. 1982. La Biochimie Clinique en Aquaculture. Interet et Perspective. CNEXO, Actes Colloq., 14: 291-326.

APHA 1998. Standard methods for the examination of water and waste water. American Public Health Association. $20^{\text {th }}$ edn. Washington, DC, USA.

Bhattacharya, T., Ray, A. K. and Bhattacharya, S. 1987. Blood glucose and hepatic glycogen interrelationship in Channa punctatus (Bloch): A parameter of nonlethal toxicity with industrial pollutants. Indian J. Exp. Biol., 25: 539-541.

Billard, R. 1999. Carp: biology and culture. Springer Praxis, New York, 342 pp.

Blaxhall, P. C. and Daisley, K. W. 1973. Routine haematological methods for use with fish blood. J. Fish. Biol., 5: 771-781.
Casillas, E. and Smith, L. S. 1977. Effect of stress on blood coagulation and haematology in rainbow trout (Salmo gairdneri). J. Fish. Biol., 10: 481-491.

Cech, G. J. and Wohlschlag, G. I. (1981). South African water quality guidelines. Department of Water Affairs and Forestry, $185 \mathrm{pp}$.

Collazos, M. E., Ortega, E., Barriga, C. and Rodriguez, A. B. 1998. Seasonal variation in haematological parameters in male and female Tinca tinca. Mol. Cell. Biochem., 183: $165-168$.

Das, P. C., Ayyappan, S., Jena, J. K. and Das, B. K. 2004. Nitrite toxicity in Cirrhinus mrigala (Ham.) - Acute toxicity and sublethal effect on selected haematological parameters. Aquaculture, 235: 633-644.

Dheer, J. M. S. 1986. Haematological and haemopoietic response to sodium chloride stress in fresh water air breathing fish Channa punctatus Bloch. J. Fish Biol., 28: 119-128.

Elliot, J. M. 1981. Some aspects of thermal stress on freshwater teleosts. In: Picketing, A. D. (Ed.), Stress and fish. Academic Press, London, p. 209-245.

Engelsma, H. J. and Frott, H. K. 2003. The haematology of Labeo Rohita. J. Fish. Biol., 13: 12-19.

Farrell, Y. U. and Robertson, G. I. 2002. Physiological effects of simulated high density transport of Atlantic cod (Gadus morhua). Aquaculture, 118: 48-52.

Garcia, M. P., Echevarria, G., Martinez, F. J. and Zamora, S. 1992. Influence of blood sample collections on the haematocrit value of two teleosts: Rainbow trout (Oncorhynchus mykiss) and European seabass (Dicentrachus labrax L.). Comp. Biochem. Physiol., 101: 733-736.

Ghosh, A. N. and Pandit, P. K. 1976. A note on the salinity tolerance of common carp, Cyprinus carpio (Linn.) under Indian conditions. J. Inland Fish. Soc. India, 8: 115-116.

Hattingh, J. 1976. Blood sugar as an indicator of stress in the freshwater fish, Labeo capensis (Smith). J. Fish. Biol., 10: 191-195.

Hickey, Y. O. and Ferrari, J. U. 1982. Phenetics of natural pollutions III. Variation in insular population of a lizard. Amer. Natur., 71: 32-38.

Hymarathi, H. P. and Rao, H. I. 1999. Changes in urine flow rate and haematocrit value of rainbow trout (Salmo gairdeneri Richardson) exposed to hypoxia. J. Fish. Biol., 45: 53-59.

Iwama, G. K., Vijayan, M. M., Forsyth, R. B. and Ackermen, P. A. 1999. Heat shock proteins and physiological stress in fish. Amer. Zool., 39: 901-909.

Meenakala, M. and Gundersen, K. L. 1978. Hypoxia induced adaptive and reversible gross morphological changes in Crucian carp gills. J. Exp. Biol., 39: 23-28.

Nelson, D. L. and Cox, M. M. 2005. Lehninger principles of biochemistry, $4^{\text {th }}$ edn. Freeman and Co., New York, $1013 \mathrm{pp}$. 
Omeregie, H. J. and Golden, G. I. 1990. Histopathological alternation of white seabass, Lates calcarifer in acute and subchronic cadmium exposure. Env. Pollut., 21: 34-38.

Pillai, D., Jose, S., Mohan, M. V. and Joseph, A. 2003. Effect of salinity on growth and survival of Rohu Labeo rohita (Ham.) under laboratory and field conditions. Fish. Technol., 40(2): 91-94.

Randall, H. I. and Prey, U. O. 1994. Temperature reception and response in fish. J. Fish. Res. Bd. Can., 11: 23-28.

Reid, H. R. and Nilson, G. K. 1998. Digestive functions in teleost fishes. In: Fish nutrition. Academic Press, New York.

Routray, P. and Routray, M. D. 1997. Growth potential of grass carp Ctenopharyngodon idella. Fish. Technol., 34: 7-10.

Siddiqui, D. L. J and Naseem, J. T. 1979. Feed deprivation and refeeding on alternation of protease in tilapia Oreochromis mossambicus. Zoological Studies, 45(3): 208-305.
Snedecor, G. W. and Cochran, W. G. 1980. Statistical methods, $7^{\text {th }}$ edn. The Iowa State University Press, USA, $505 \mathrm{pp}$.

Strange, G. U. and Spencer, K. T. 1977. The blood oxygen binding properties of hypoxic Salmo gairdeneri. J. Comp. Physiol., 21: 32-38.

Wedemeyer, G. A. 1972. Some physiological consequences of handling stress in the juvenile coho salmon (Onchorhyncus kisutch) and rainbow trout (Salmo gairdneri) to handling and crowding in intensive fish culture. J. Fish. Res. Bd. Can., 33: 2699-2702.

Wiik, S. O. and Hoffman, G. E. 1989. Salinity as a selective factor in protein evaluation: the adoptational strategy of compromise. J. Exp. Zool., 76: 49-54.

Zhou, R. O. P. and Lloyd, Y. O. 2000. Corticoid stress response to handling and temperature in salmonids. Trans. Am. Fish. Soc., 67: 87-93.

Date of Receipt $\quad$ : 12.07.2013

Date of Acceptance : 03.03.2016 